\title{
PENURUNAN CACAT PRODUK GARNISH-ASSEMBLY TAILGATE DI PERUSAHAAN OTOMOTIF MELALUI PENDEKATAN METODE DMAIC
}

\author{
Aina Nindiani, Robi Nursikin, Ali Kustia, Tedi Sertiadi, \\ Ni Wayan Puji, Wahyudi \\ Program Studi Teknik Industri, Universitas Buana Perjuangan Karawang \\ Jl. HS. Ronggowaluyo Telukjambe Timur, Karawang 41361 \\ email:aina.nindiani@gmail.com
}

\begin{abstract}
ABSTRAK
Penelitian ini bertujuan untuk melakukan upaya perbaikan dalam menurunkan cacat produk Garnish-Assembly Tailgate pada proses painting menggunakan pendekatan metode DMAIC (Define, Measure, Analyze, Improve, Control). Berdasarkan diagram Pareto, cacat yang mendominasi pada produk GarnishAssembly Tailgate adalah cacat butsu dan hajiki. Langkah perbaikan dilakukan menggunakan FMEA (Failure Modes and Effects Analysis) dapat menurunkan jumlah cacat produk ini, yang ditunjukkan dengan penurunan nilai DPMO (Defects per Million Opportunities) sebesar 31,91\% serta peningkatan nilai sigma dari 2,90 menjadi 3,10.
\end{abstract}

Kata Kunci: DMAIC, DPMO, Six Sigma, FMEA

\section{PENDAHULUAN}

Perkembangan teknologi yang begitu pesat dapat mempengaruhi kemajuan dari berbagai bidang kehidupan. Seperti halnya yang terjadi pada bidang industri, berbagai sektor terus berupaya untuk meningkatkan mutu atau kualitas atas produk yang dihasilkannya. Orientasi customer saat ini perlahan mulai bergeser untuk memberikan perhatian lebih terhadap kualitas. Dengan demikian suatu perusahaan dituntut untuk bisa memenuhi keinginan dan kebutuhan pelanggannya apabila ingin bertahan dalam mengarungi persaingan kegiatan bisnis yang semakin ketat. Komitmen perusahaan dalam meningkatkan mutu atau kualitas dan memenuhi kebutuhan pelanggan demi menjaga kepuasan pelanggan yaitu dengan menerapkan sistem manajemen kualitas yaitu ISO. Akan tetapi perusahaan harus selalu melakukan perbaikan yang berkelanjutan karena pada kenyataan masih banyak perusahaan yang menerapkan manajemen sistem mutu ISO, namun masih menghasilkan produk-produk yang tidak memenuhi spesifikasi produk yang ditentukan, yang dinamakan dengan produk yang cacat (defect).

Penelitian ini dilakukan pada perusahaan otomotif di Karawang yang memproduksi part eksterior untuk kendaraan roda empat. Salah satu produk yang dihasilkan adalah Garnish-Assembly Tailgate. Produksi Garnish-Assembly Tailgate sering sekali menghasilkan cacat produk terutama pada proses painting. Dalam satu bulan tercatat tak kurang dari 50\% produk mengandung cacat akibat dari proses painting, sehingga memerlukan pengerjaan ulang (rework). 
Besarnya tingkat cacat yang dihasilkan oleh suatu perusahaan tentu akan berpengaruh terhadap daya saing perusahaan. Oleh karena itu perusahaan harus berusaha untuk mengendalikan kualitas proses dan produknya dengan sebaikbaiknya, sehingga tingkat cacat dapat berkurang. Pengendalian kualitas dapat dilakukan dengan beberapa metode seperti teknik-teknik stastik dan metode lainnya (Gazpersz, 2003). Suatu proses produksi terdapat variasi-variasi proses yang dapat menyebabkan gangguan pada kualitas produk-produk yang dihasilkannya. Oleh karena itu diperlukan pengurangan variasi-variasi tersebut. Maka perlu digunakan sebuah metode yang dapat mengidentifikasi sebab-sebab dari variasi tersebut dan melakukan perbaikan pada masalah yang dianggap sebagai prioritas. Tidak semua penyebab dapat diatasi secara sekaligus.

DMAIC (Define, Measure, Analyse, Improve, Control) adalah tahapan dalam konsep pendekatan Six Sigma yang dapat digunakan untuk mengurangi variasi proses dalam meminimalisir cacat produk yang dihasilkan dengan perbaikan terus menerus (continuous improvement). Menurut Kiran (2017), metodologi DMAIC merupakan pengembangan dari PDCA (Plan-Do-Check-Act) yang merupakan metodologi TQM populer dari pakar kualitas Deming. Metode DMAIC ini dilakukan untuk dapat mencapai sigma level secara efektif.

Beberapa penelitian telah dilakukan menggunakan pendekatan DMAIC di bidang manufaktur, seperti Gupta (2013) yang meneliti tentang perbaikan kualitas pada pabrik pembuatan benang. Penelitian tersebut bertujuan untuk menurunkan tingkat cacat produk pada proses penggulungan (winding) sebagai penyumbang cacat terbesar. Metodologi DMAIC dilakukan untuk mengurangi peluang kegagalan dari produk akhir benang yang dihasilkan. Sharma dan Rao (2014) meneliti operasi pengeboran pada produksi crankshaft untuk mengurangi variasi proses menggunakan pendekatan DMAIC dan berhasil mengurangi standar deviasi dari 0,003 menjadi 0,002. Caesaron dan Simatupang (2015) meneliti cacat pada proses produksi pipa PVC menggunakan pendekatan DMAIC dan diketahui level sigma sebesar 3,97 dan DPMO sebesar 6722,963. Penelitian tersebut memberikan usulan perbaikan untuk mengurangi cacat namun tidak sampai pada tahap implementasi perbaikan. Purba et al. (2018) meneliti peningkatan quality awareness menggunakan pendekatan DMAIC di perusahaan part otomotif. Tujuannya adalah untuk menetapkan aturan dasar, mengembangkan struktur untuk mencegah lolosnya produk cacat ke pasar, membangun struktur untuk mencegah cacat diteruskan ke proses berikutnya serta menjaga standardisasi keterampilan dalam pekerjaan. Sedangkan penelitian ini bertujuan untuk meningkatkan kualitas produksi Garnish-Assembly Tailgate dengan mengurangi tingkat cacat produk yang terjadi pada proses painting.

\section{METODOLOGI PENELITIAN}

Penelitian ini dilakukan pada produk Garnish-Assembly Tailgate dengan mengambil sampel produk pada proses painting. Dalam penelitian ini dibutuhkan beberapa data yaitu data cacat produk Garnish-Assembly Tailgate yang terjadi pada proses painting serta penyebab terjadinya cacat produk tersebut yang diperoleh dengan pengamatan langsung dan wawancara dengan penanggung jawab bagian proses painting. 
Data cacat tersebut kemudian diolah ke dalam metode DMAIC yang meliputi lima tahap yaitu Define, Measure, Analyze, Improve dan Control. Menurut Kiran (2017), metodologi DMAIC ditampilkan pada Gambar 1.

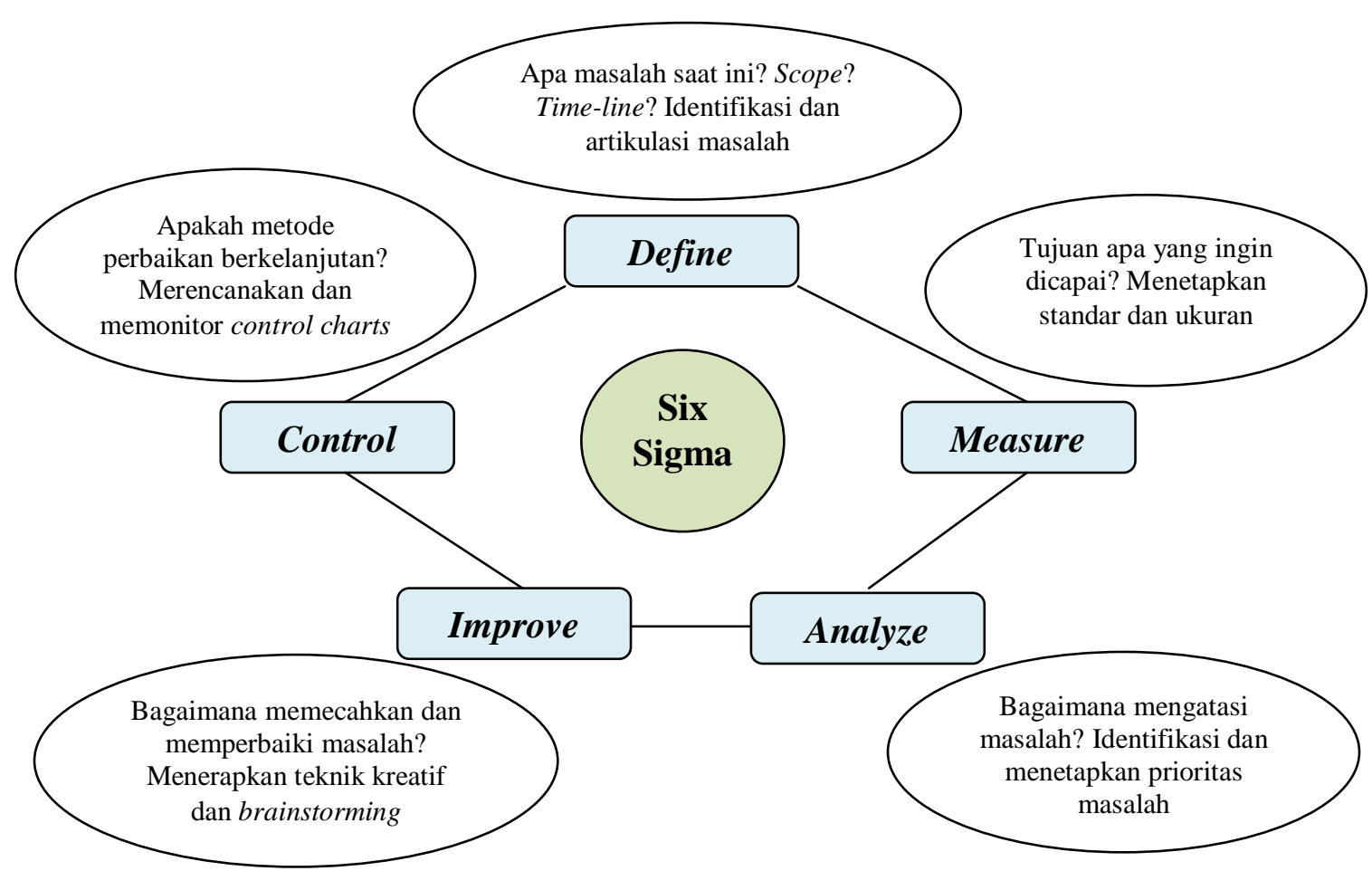

Gambar 1 Metodologi DMAIC

Sumber: Kiran (2017)

\section{Tahap Define}

Define merupakan tahapan dalam menetapkan masalah yang terjadi, yang dapat mencakup Critical to Quality (CTQ).

\section{Tahap Mesaure}

Measure merupakan tahap kedua yang merupakan dasar untuk improvement dengan mengumpulkan data-data yang relevan untuk kemudian dilakukan pengukuran. Data yang relevan dan substansial merupakan jantungnya proses DMAIC. Pada tahap ini dapat dilakukan berbagai pengukuran seperti mengukur DPMO dan sigma level serta mengembangkan $Q C$ tools.

\section{Tahap Analyze}

Analyze merupakan langkah ketiga yang bertujuan untuk mengidentifikasi akar penyebab dari permasalahan yang terjadi, memvalidasi serta memilih metode untuk mengeliminasinya. Diagram fishbone dapat dipakai untuk memvalidasi penyebab masalah hingga ke akarnya. Prioritas penyebab potensial dari masalah diambil untuk mendukung tahap Improve. 


\section{Tahap Improve}

Improve merupakan tahap keempat, dimana pada tahap ini dikembangkan solusi dari masalah yang terjadi serta upaya untuk memperbaikinya. Tujuannya adalah mengidentifikasi solusi masalah untuk bagian tertentu atau untuk keseluruhan. Tahap ini melibatkan konsep kreativitas dan beberapa yang dapat dilakukan seperti melakukan brainstorming, PDCA, Taguchi atau FMEA (Failure Modes and Effects Analysis).

\section{Tahap Control}

Pada tahap terakhir ini bertujuan untuk menopang pencapaian secara berkelanjutan, memonitor improvements untuk menjamin kesuksesan secara terusmenerus, membuat control plan, mengupdate dokumen, proses bisnis dan catatancatatan yang diperlukan. Control chart sangat bermanfaat dalam tahap control untuk melihat stabilitas improvement yang dilakukan dari waktu ke waktu.

\section{HASIL DAN PEMBAHASAN}

\section{Tahap Define}

Tahap Define dilakukan dengan menentukan sasaran serta tujuan dari perbaikan dalam penelitian ini yaitu produk Garnish-Assembly Tailgate. Produk ini dipilih karena perusahaan otomotif ini memproduksi secara rutin setiap bulan. Berdasarkan spesifikasi yang ditetapkan oleh perusahaan, maka identifikasi CTQ untuk produk Garnish-Assembly Tailgate agar dapat diterima oleh pelanggan adalah produk bebas dari tujuh jenis cacat yaitu butsu, tare, scratch, benang, hajiki, no clear dan mura. Butsu adalah cacat bintik dimana terdapat partikel kotoran yang menempel pada lapisan cat yang masih basah dan menempel hingga cat mengering. Tare adalah lelehan cat karena terlalu banyak cat yang menempel di permukaan produk. Scratch adalah cacat goresan pada cat yang dapat disebabkan terkena suatu benda. Benang adalah cacat yang berbentuk serat yang menempel pada permukaan cat. Hajiki adalah cacat yang berbentuk seperti kawah yang terbuka seperti mata ikan setelah cat diaplikasikan. No clear adalah cacat yang terlihat buram setelah cat diaplikasikan. Mura adalah cacat yang terlihat belang pada produk setelah cat diaplikasikan.

\section{Tahap Measure}

Pada tahap Measure, dilakukan pengumpulan data jumlah cacat yang terjadi serta dilakukan perhitungan persentase cacat tersebut terhadap total cacat secara keseluruhan, serta dilakukan perhitungan DPMO (Defects per Million Opportunities). Jumlah cacat produksi dalam satu bulan dapat dilihat pada Tabel 1. 
Tabel 1. Cacat Produksi Garnish-Assembly Tailgate

\begin{tabular}{|c|c|c|c|}
\hline Jenis Cacat & $\begin{array}{c}\text { Jumlah } \\
\text { Cacat }\end{array}$ & $\begin{array}{c}\text { Persentase } \\
(\boldsymbol{\%})\end{array}$ & $\begin{array}{c}\text { Akumulasi } \\
\text { Persentase (\%) }\end{array}$ \\
\hline Butsu & 367 & 44,65 & 44,65 \\
\hline Hajiki & 248 & 30,17 & 74,82 \\
\hline Benang & 165 & 20,07 & 94,89 \\
\hline Scratch & 26 & 3,16 & 98,05 \\
\hline Tare & 9 & 1,09 & 99,15 \\
\hline No clear & 6 & 0,73 & 99,88 \\
\hline Mura & 1 & 0,12 & 100,00 \\
\hline Total & 822 & 100,00 & \\
\hline
\end{tabular}

Sumber: Data Perusahaan, diolah (2018)

Berdasarkan Tabel 1 dapat diketahui bahwa cacat yang terjadi dalam satu bulan berjumlah 822 dari total produk yang dihasilkan sebanyak 1473 unit. Dengan demikian maka nilai DPMO dapat dihitung sebagai berikut:

$$
\begin{aligned}
& =\left(\frac{D}{(U \times O)}\right) * 1000000 \\
& =\left(\frac{822}{(1473 \times 7)}\right) * 1000000 \\
& =79720,69 \mathrm{DPMO}
\end{aligned}
$$

Pada perhitungan di atas, D adalah jumlah defect (cacat) produk yang terjadi pada unit sampel, $\mathrm{U}$ adalah unit sampel dan $\mathrm{O}$ adalah defect opportunity per unit sampel. Nilai DPMO yang diperoleh adalah sebesar 79720,69 DPMO. Nilai ini bila dikonversi ke nilai sigma adalah sebesar 2,90 sigma.

Berdasarkan Tabel 1 dapat dibuat diagram Pareto untuk melihat prioritas perbaikan pada cacat yang terjadi yang akan menjadi CTQ (Critical to Quality). Diagram Pareto dapat dilihat pada Gambar 2. 


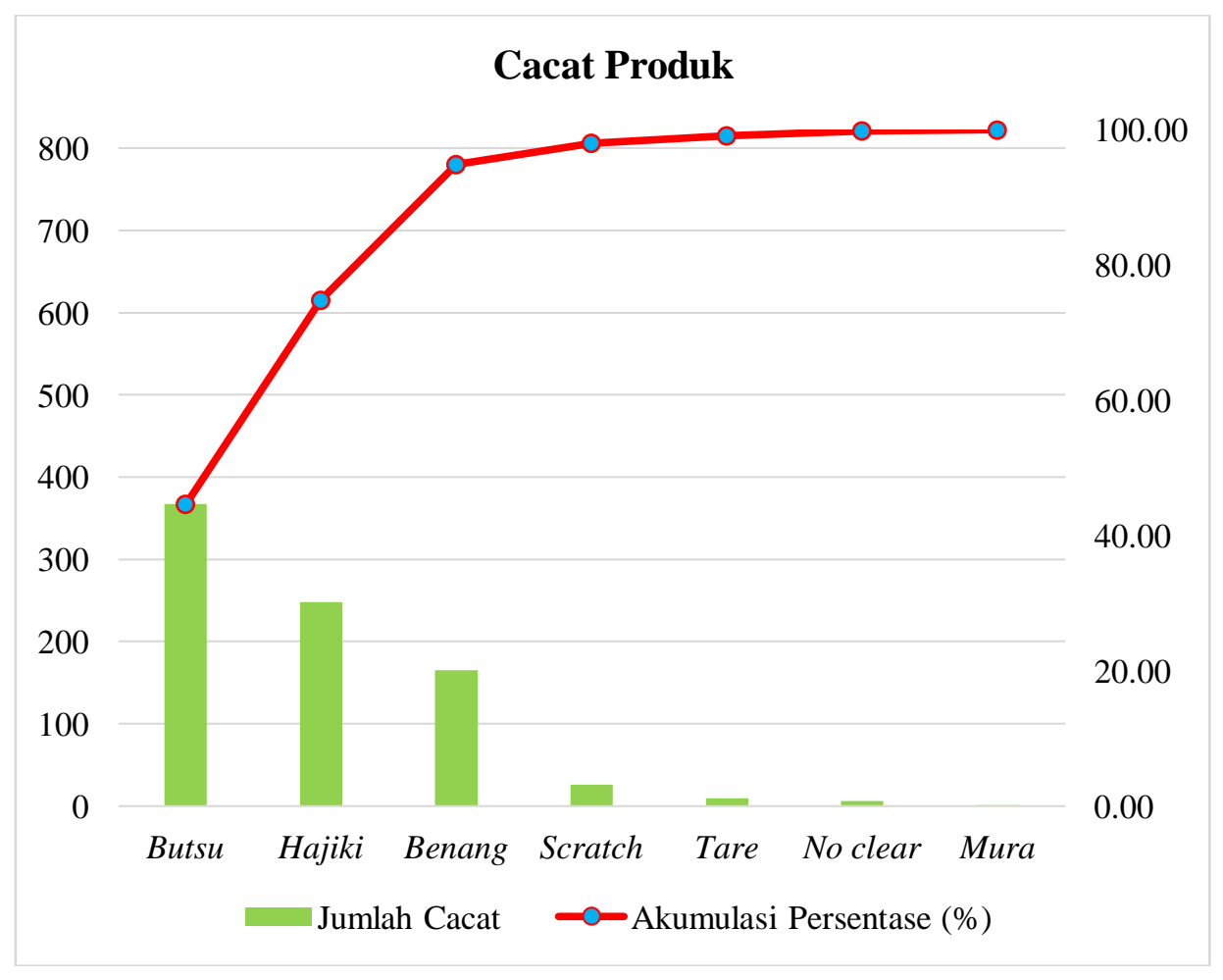

Gambar 2. Diagram Pareto Cacat Produk Garnish-Assembly Tailgate

Dari hasil perhitungan diagram pareto pada Gambar 1 didapatkan hasil bahwa jenis cacat yang dominan terjadi pada produk Garnish-Assembly Tailgate (yang memberikan kontribusi jumlah cacat mendekati 80\%) dan yang diprioritaskan sebagai CTQ adalah jenis cacat Butsu dan Hajiki. Kedua jenis cacat ini yang menjadi prioritas untuk dilakukan tindakan perbaikan.

\section{Tahap Analyze}

Setelah melalui tahap measure dapat diperoleh data bahwa cacat produk yang dominan dan dinamakan sebagai CTQ adalah cacat produk butsu dan hajiki. Selanjutnya akan dianalisis dan dievaluasi faktor-faktor yang menjadi penyebab terjadinya cacat produk tersebut dengan dijabarkan dalam bentuk diagram sebab akibat (fishbone diagam).

Diagram sebab akibat merupakan metode pendekatan analisis terhadap suatu masalah yang lebih terperinci sehingga dapat diketahui akar-akar masalah yang menjadi penyebab utama terjadinya cacat produk. Pada diagram sebab akibat dilakukan analisis faktor penyebab terjadinya cacat dari empat faktor material, machine, man dan method. Melalui diagram sebab akibat pada Gambar 3 dapat dilihat bahwa penyebab terjadinya cacat Butsu pada produk GarnishAssembly Tailgate ditinjau dari faktor mesin dapat disebabkan karena kondisi selang spraygun dan pompa yang kotor, proses pencucian selang maupun pompa yang tidak maksimal sehingga masih terdapat sisa-sisa kotoran pada selang dan pompa. Sedangkan dari faktor metode di lapangan yaitu proses penyaringan 
material cat dengan mesh 300 tidak efektif dan pada saat pembersihan material sozay pada proses wiping tidak bersih. Butsu disebabkan juga karena material cat terdapat kotoran begitu juga pada material clear. Pada faktor manusia dapat disebabkan oleh kurangnya awareness terhadap produk yang dihasilkan.

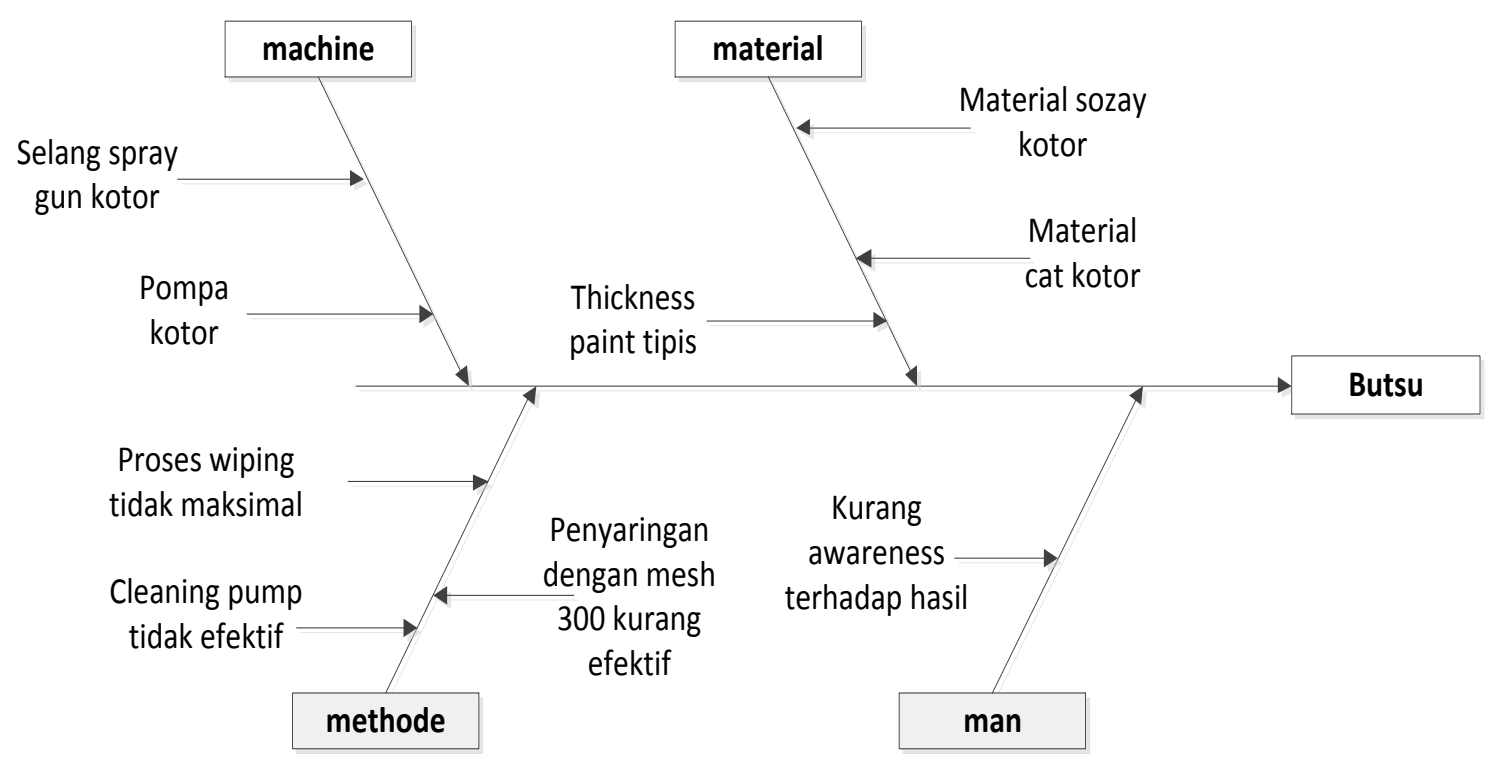

Gambar 3. Diagram Sebab Akibat Cacat Butsu

Sedangkan untuk jenis cacat Hajiki pada proses painting dapat disebabkan oleh beberapa faktor. Faktor-faktor penyebab digambarkan pada diagram sebab akibat Gambar 4. Cacat Hajiki dianalisis dari faktor mesin dapat disebabkan beberapa hal yaitu: (1) suhu oven terlalu tinggi, hal ini dapat menyebabkan pemanasan pada part yang terlalu cepat sehingga pada lapisan base dan clear cepat bereaksi, (2) setelan pada spray gun tidak sesuai, ini dapat menyebabkan pada ketebalan cat terlalu tipis. Kemudian dari faktor material, Hajiki terjadi karena viskositas cat terlalu tinggi sehingga cat terlalu encer dan ketika proses painting ketebalan cat tipis. Hajiki dapat dipengaruhi juga karena ketidaksesuaian penggunaan thinner, karena dengan thinner yang tidak sesuai dapat menyebabkan penguapan terlalu cepat. Selanjutnya dari faktor metode sesuai dengan analisa pada faktor mesin dan faktor material yaitu kondisi ketebalan base dan clear kurang tebal. Curing time atau waktu tunggu sebelum di oven terlalu pendek. Faktor penyebab dari man power adanya ketidaksesuaian setelan spray gun dengan setelan yang telah ditentukan yang dapat menyebabkan mempengaruhi hasil painting serta kurangnya kontrol terhadap penggunaan mesin seperti pengecekan oven atau spray gun yang digunakan. 


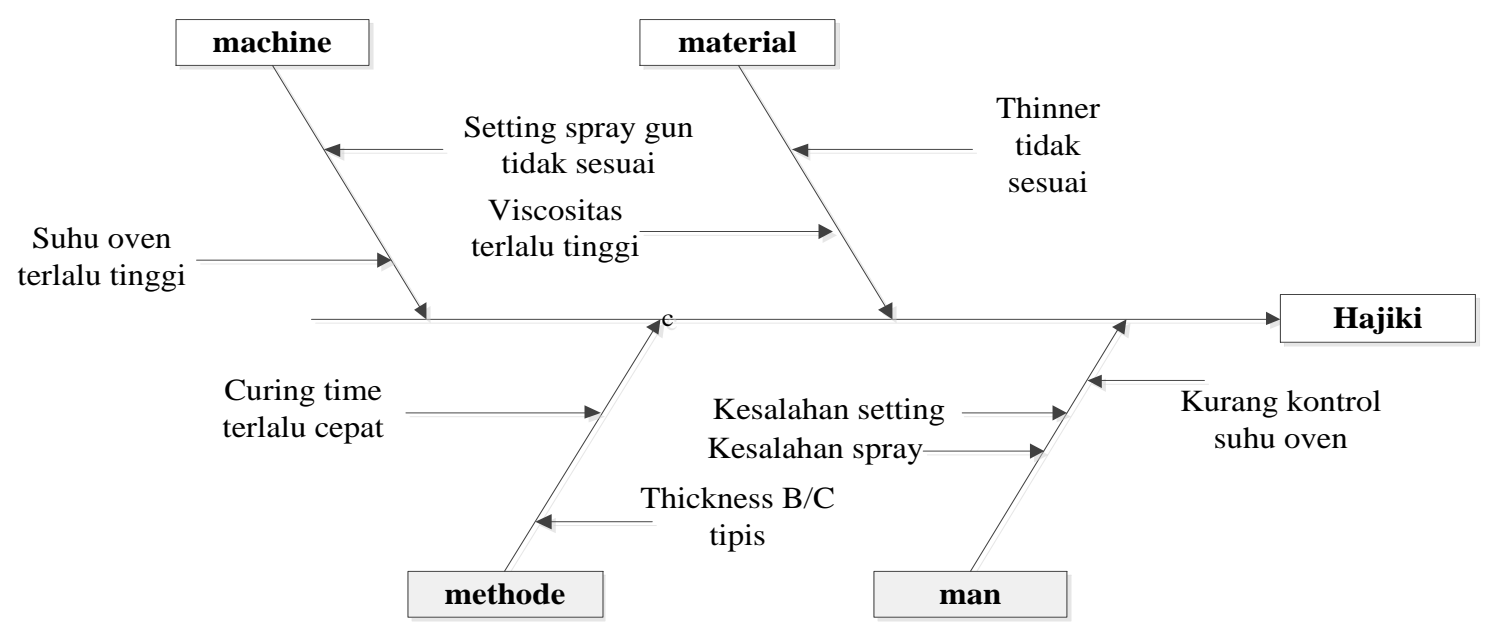

Gambar 4. Diagram Sebab Akibat Cacat Hajiki

\section{Tahap Improve}

Pada tahap Improve ini, dilakukan perbaikan menggunakan metode Failure Modes and Effects Analysis (FMEA) untuk meningkatkan kualitas proses berdasarkan pada tahap analisis yang telah dilakukan. FMEA dilakukan untuk memberikan judgement terhadap nilai severity (tingkat keparahan), occurence (tingkat kejadian) dan detection (kemudahan dalam pendeteksian) oleh penanggung jawab bagian painting. Setelah itu dilakukan perhitungan RPN dengan mengalikan ketiga nilai tersebut. FMEA ditampilkan pada tabel 2. Pada tabel tersebut dapat dilihat bahwa penyebab yang memiliki nilai RPN tinggi adalah spray gun kotor yang disebabkan karena pencucian selang dan pompa tidak maksimal karena jadwal pencucian yang telah ditentukan tidak efektif, serta pada proses penyaringan material cat yang menggunakan mesh 300 juga menjadi penyebab munculnya cacat Butsu dan Hajiki cukup tinggi kontribusinya. sehingga penyebab tersebut menjadi prioritas untuk dilakukan perbaikan karena memiliki kontribusi terhadap terjadinya cacat produk. Perhitungan DPMO setelah dilakukan improvement adalah sebagai berikut:

$$
\begin{aligned}
& =\left(\frac{D}{(U \times O)}\right) * 1000000 \\
& =\left(\frac{627}{(1650 \times 7)}\right) * 1000000 \\
& =54285,71 \mathrm{DPMO}
\end{aligned}
$$

Nilai DPMO yang dihasilkan adalah 54285,71 DPMO yang berarti terjadi penurunan DPMO sebesar 31,91\%. Apabila nilai DPMO dikonversikan ke dalam nilai sigma, maka perbaikan yang telah dilakukan terhadap penyebab-penyebab terjadinya cacat memberikan nilai sigma sebesar 3,10 . 
Tabel 2 Tabel Failure Modes and Effects Analysis

\begin{tabular}{|c|c|c|c|c|c|c|c|c|c|}
\hline $\begin{array}{l}\text { Process } \\
\text { Function }\end{array}$ & $\begin{array}{l}\text { Potential } \\
\text { Failure } \\
\text { Mode }\end{array}$ & $\begin{array}{l}\text { Potential } \\
\text { Effect(s) of } \\
\text { Failure }\end{array}$ & Severity & $\begin{array}{c}\text { Potential } \\
\text { Cause(s)/ } \\
\text { Mechanism( } \\
\text { s) of Failure }\end{array}$ & $\begin{array}{l}\text { Occur } \\
\text { ence }\end{array}$ & $\begin{array}{c}\text { Current Process } \\
\text { Controls } \\
\text { Detection }\end{array}$ & $\begin{array}{l}\text { Detecti } \\
\text { on }\end{array}$ & $R P N$ & $\begin{array}{c}\text { Recommended } \\
\text { Action (s) }\end{array}$ \\
\hline \multirow{2}{*}{ Wiping } & \multirow{2}{*}{$\begin{array}{l}\text { Wiping } \\
\text { tidak } \\
\text { maksimal }\end{array}$} & Butsu & 4 & \multirow{2}{*}{$\begin{array}{l}\text { Kain wiping } \\
\text { kotor }\end{array}$} & 6 & Cek kondisi kain & 8 & 192 & \multirow{2}{*}{$\begin{array}{l}\text { Penggantian } \\
\text { kain setiap } 30- \\
40 \text { produk } \\
\text { sekali }\end{array}$} \\
\hline & & Hajiki & 4 & & 6 & $\begin{array}{l}\text { Penggantian kain } \\
\text { ketika kotor }\end{array}$ & 8 & 192 & \\
\hline \multirow{5}{*}{ Mixing } & $\begin{array}{l}\text { Viskositas } \\
\text { tinggi }\end{array}$ & $\begin{array}{l}\text { Ketebalan } \\
\text { cat tipis }\end{array}$ & 3 & $\begin{array}{l}\text { Tidak sesuai } \\
\text { sandar }\end{array}$ & 7 & $\begin{array}{l}\text { Lembar } \\
\text { pengecekan } \\
\text { mixing }\end{array}$ & 8 & 168 & $\begin{array}{l}\text { Kontrol man } \\
\text { power }\end{array}$ \\
\hline & \multirow{2}{*}{$\begin{array}{l}\text { Thinner } \\
\text { tidak } \\
\text { sesuai }\end{array}$} & Hajiki & 5 & $\begin{array}{l}\text { Salah } \\
\text { pengambil- } \\
\text { an thinner }\end{array}$ & 3 & $\begin{array}{l}\text { Pemberian label } \\
\text { produk }\end{array}$ & 8 & 120 & \\
\hline & & $\begin{array}{l}\text { painting } \\
\text { tidak kuat }\end{array}$ & 5 & $\begin{array}{c}\text { Salah } \\
\text { pengiriman } \\
\text { dari supplier }\end{array}$ & 4 & $\begin{array}{l}\text { Tidak dilakukan } \\
\text { cek aktual }\end{array}$ & 8 & 160 & $\begin{array}{c}\text { Trial setiap } \\
\text { kedatangan lot } \\
\text { baru }\end{array}$ \\
\hline & \multirow[t]{2}{*}{$\begin{array}{l}\text { Penyari- } \\
\text { ngan tidak } \\
\text { maksimal }\end{array}$} & Butsu & 5 & $\begin{array}{l}\text { Mesh tidak } \\
\text { sesuai }\end{array}$ & 8 & $\begin{array}{l}\text { Menggunakan } \\
\text { mesh ukuran } 300\end{array}$ & 9 & 360 & $\begin{array}{l}\text { Menggunakan } \\
\text { mesh } 500\end{array}$ \\
\hline & & Hajiki & 5 & $\begin{array}{c}\text { Material } \\
\text { terlalu kotor }\end{array}$ & 7 & $\begin{array}{c}\text { Cek kondisi warna } \\
\text { cat }\end{array}$ & 8 & 280 & $\begin{array}{c}\text { Trial setiap } \\
\text { kedatangan lot } \\
\text { baru }\end{array}$ \\
\hline \multirow{7}{*}{ Spraying } & \multirow{3}{*}{$\begin{array}{l}\text { Spray gun } \\
\text { kotor }\end{array}$} & Butsu & 5 & $\begin{array}{l}\text { Selang spray } \\
\text { gun kotor }\end{array}$ & 8 & $\begin{array}{c}\text { Dicuci setiap akan } \\
\text { proses }\end{array}$ & 8 & 320 & $\begin{array}{c}\text { Pencucian } \\
\text { dilakukan akan } \\
\text { proses dan } \\
\text { ganti model }\end{array}$ \\
\hline & & Hajiki & 5 & $\begin{array}{l}\text { Pencucian } \\
\text { tidak } \\
\text { maksimal }\end{array}$ & 8 & $\begin{array}{l}\text { Menggunakan } \\
\text { cairan pembersih }\end{array}$ & 9 & 360 & $\begin{array}{c}\text { Pencucian } \\
\text { dilakukan dua } \\
\text { kali setiap kali } \\
\text { pencucian }\end{array}$ \\
\hline & & Dust spray & 6 & $\begin{array}{c}\text { Schedule } \\
\text { pencucian } \\
\text { pompa tidak } \\
\text { efektif }\end{array}$ & 7 & $\begin{array}{l}\text { Cleaning setiap } 1 \\
\text { bulan sekali }\end{array}$ & 9 & 378 & $\begin{array}{c}\text { Cleaning } \\
\text { schedule setiap } \\
1 \text { minggu sekali }\end{array}$ \\
\hline & \multirow{2}{*}{$\begin{array}{l}\text { Setelan } \\
\text { spray gun } \\
\text { salah }\end{array}$} & $\begin{array}{l}\text { Ketebalan } \\
\text { cat tipis }\end{array}$ & 5 & $\begin{array}{c}\text { Tidak } \\
\text { mengikuti } \\
\text { instruksi } \\
\text { kerja }\end{array}$ & 6 & $\begin{array}{l}\text { Cek visual, job } \\
\text { setting }\end{array}$ & 8 & 240 & $\begin{array}{l}\text { kontrol man } \\
\text { power }\end{array}$ \\
\hline & & Cat leleh & 5 & $\begin{array}{l}\text { Kesalahan } \\
\text { setting }\end{array}$ & 5 & $\begin{array}{l}\text { Cek visual, job } \\
\text { setting }\end{array}$ & 8 & 200 & $\begin{array}{c}\text { Cek kembali } \\
\text { setelah setting }\end{array}$ \\
\hline & \multirow{2}{*}{$\begin{array}{l}\text { Proses } \\
\text { spray tidak } \\
\text { sesuai }\end{array}$} & $\begin{array}{c}\text { Curing time } \\
\text { terlalu } \\
\text { cepat }\end{array}$ & 4 & $\begin{array}{c}\text { Spray lapisan } \\
\text { base tidak } \\
\text { sesuai }\end{array}$ & 4 & $\begin{array}{l}\text { Berdasarkan } \\
\text { instruksi kerja }\end{array}$ & 7 & 112 & \\
\hline & & $\begin{array}{l}\text { Ketebalan } \\
\text { cat tipis }\end{array}$ & 4 & $\begin{array}{c}\text { Spray lapisan } \\
\text { clear tidak } \\
\text { sesuai }\end{array}$ & 4 & $\begin{array}{l}\text { Berdasarkan } \\
\text { instruksi kerja }\end{array}$ & 8 & 128 & \\
\hline \multirow{2}{*}{ Drying } & \multirow{2}{*}{$\begin{array}{l}\text { Oven tidak } \\
\text { sesuai }\end{array}$} & $\begin{array}{c}\text { Pemanasan } \\
\text { terlalu } \\
\text { cepat }\end{array}$ & 4 & $\begin{array}{l}\text { Suhu oven } \\
\text { tinggi }\end{array}$ & 5 & $\begin{array}{c}\text { Lembar } \\
\text { pengecekan oven }\end{array}$ & 8 & 160 & $\begin{array}{l}\text { Kontrol suhu } \\
\text { oven }\end{array}$ \\
\hline & & $\begin{array}{l}\text { painting } \\
\text { tidak kuat }\end{array}$ & 4 & $\begin{array}{l}\text { Suhu oven } \\
\text { rendah }\end{array}$ & 5 & Cruss cut test & 7 & 140 & \\
\hline
\end{tabular}

Sumber: Data Perusahaan, diolah (2018) 


\section{Tahap Control}

Pada tahapan ini merupakan tahapan terpenting karena tidak ingin masalah yang terjadi terulang kembali maka dari itu dibuatkan sitem rencana kontrol (control plan) untuk setiap proses. Untuk pengendalian proses dan kontrol dilakukan menggunakan SPC (Statistical Process Control). Peta kendali dibuat untuk mengetahui konsistensi produk setelah dilakukan proses perbaikan. Peta kendali np chart dapat dilihat pada Gambar 5 dan Gambar 6.

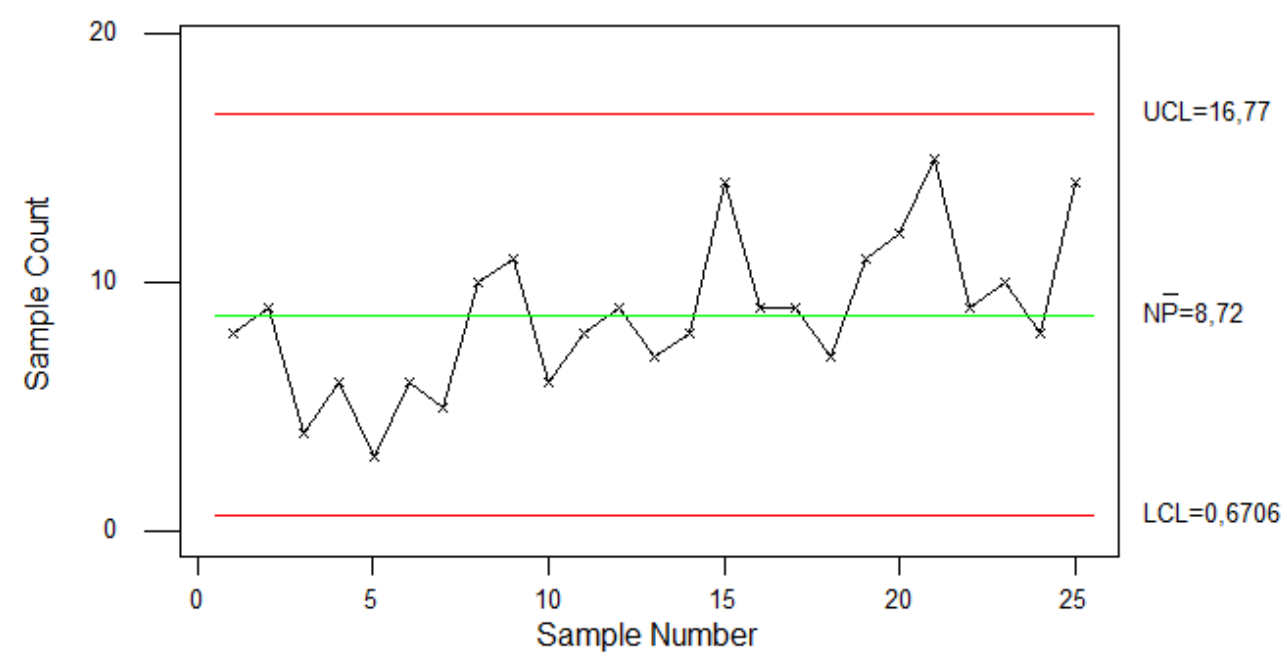

Gambar 5 Np Chart Cacat Butsu

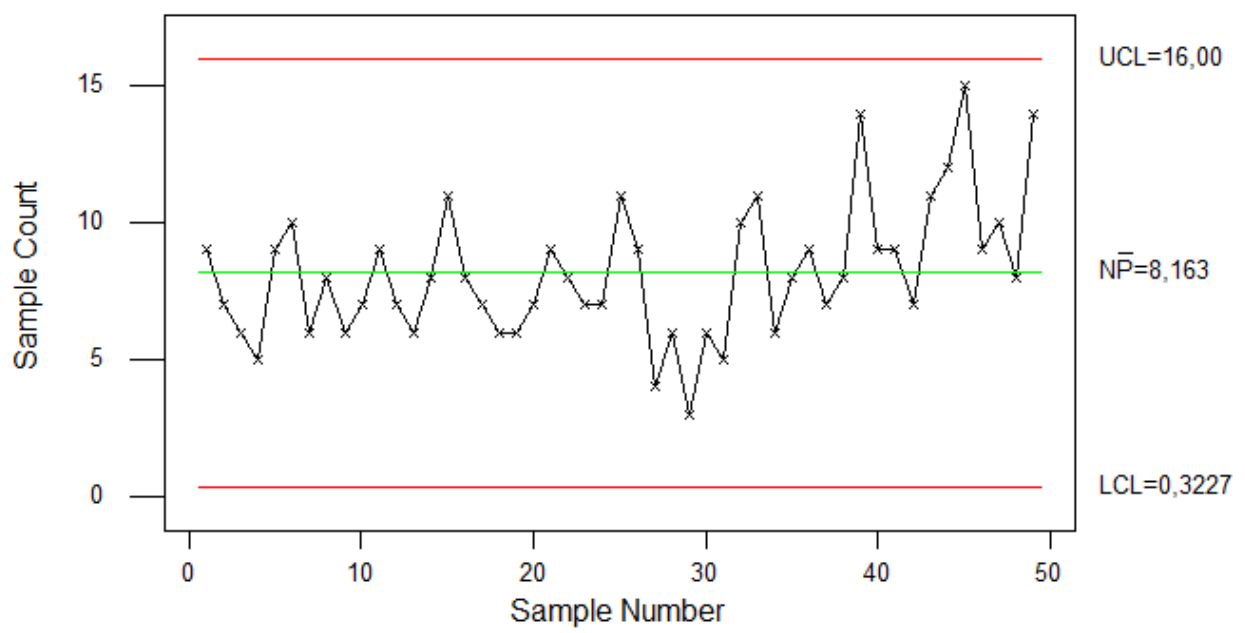

\section{Gambar 6 Np Chart Cacat Hajiki}

Dari peta kendali tersebut dapat dilihat bahwa cacat Butsu dan Hajiki dalam keadaan terkendali, berada dalam kedua batas spesifikasi UCL dan LCL. 


\section{KESIMPULAN}

Metode DMAIC dapat dipergunakan untuk meningkatkan kualitas produk Garnish-Assembly Tailgate dengan menurunkan tingkat cacat yang dihasilkan. Berdasarkan analisis dan perbaikan yang telah dilakukan, maka metode ini dapat menurunkan nilai DPMO sebesar 31,91\% dari nilai DPMO awal sebesar 72790,69 DPMO. Hasil penelitian ini mendukung penelitian terdahulu oleh Gupta (2013) bahwa pendekatan DMAIC dapat digunakan untuk meningkatkan kualitas atau minimalisasi defect produk. Perusahaan harus terus melakukan perbaikan berkelanjutan agar dapat meningkatkan kualitas produk yang dihasilkannya.

\section{DAFTAR PUSTAKA}

Caesaron, D. dan Simatupang, S.Y.P. (2015). Implementasi Pendekatan DMAIC untuk Perbaikan Proses Produksi Pipa PVC (Studi Kasus PT. Rusli Vinilon). Jurnal Metris, 16, 91-96.

Gaspersz, V. (2003). Metode Analisis untuk Peningkatan Kualitas. Jakarta: PT Gramedia Pustaka Utama.

Gupta, N. (2013). An Application of DMAIC Methodology for Increasing the Yarn Quality in Textile Industry. IOSR Journal of Mechanical and Civil Engineering, 6 (1), 50-65.

Kiran, D.R. (2017). Total Quality Management Key Concepts and Case Studies. United Kingdom: Elsevier.

Purba, H.H., Azizah, I.N., dan Lestari, R. (2018). Quality Awareness Increase with DMAIC Approach: A Case Study in Automotive Part Manufacturing in Indonesia. International Journal of Scientific Research Engineering \& Technology (IJSRET), 7 (5), 434-441.

Sharma, G.V.S.S. dan Rao, P.S. (2014). A DMAIC Approach for Process Capability Improvement an Engine Crankshaft Manufacturing Process. Journal of Industrial Enginering International, 10 (65), 1-11. 